Studies in English Drama and Poetry Vol. 3

\author{
Anna Krawczyk-Laskarzewska \\ University of Warmia and Mazury in Olsztyn
}

\title{
"Smilers, Defilers, Reekers and Leakers" - Dogs as Tools of Subversion and Transgression in Short Stories by Edgar A. Poe, Mark Twain and Ambrose Bierce
}

\begin{abstract}
In this article I will analyze three satirical stories written by Edgar A. Poe, Ambrose Bierce and Mark Twain. The common denominator of them is the presence of dogs and their eccentric subject matter and controversial narrative strategies have for many decades been treated as a major offense against the standards of literary taste. A closer analysis of such thoughtprovoking and critically underrated tales as "Toby Dammit," "Oil of Dog" or "A Dog's Tale" makes it evident that their powerful effect is possible thanks to transgression and subversion of generic expectations and aesthetic norms as well as social, political and religious issues that dominated the public discourse in the nineteenth-century United States. Furthermore, what might be perceived as a temporary rebellion or a mere irregularity in the literary oeuvre of three unquestionably canonical nineteenth-century writers is, in fact, a conscious, if risky, attempt on the part of Poe, Twain and Bierce to offer meaningful diagnoses of a society whose values and behaviours appear to be even more disgusting and irrational than the bizarre and often highly disturbing plotlines and extreme experiences in the fictitious worlds they created.
\end{abstract}

Autobiography's urge toward self-knowledge is mirrored by satire's urge to make people know themselves, tempered by the ironic awareness that self-deception is the pervasive human disease. (New 513)

In his study of subversions and scandals in the nineteenth- and twentiethcentury art, Anthony Julius offers the following comment:

To describe an artwork as 'transgressive' is to offer it a compliment. . . It is successor to the Romantic ideology of the artist as genius, a rulebreaker indifferent to art's constraints. . . . The transgressive also has a certain political flavour, opposing the stereotypical and the selfenclosed, and generating the 'open' and the 'hybrid.'. . Boundary-breaking is to be admired; it resonates with everything that is fluid, fresh, unencumbered, mobile - and 'cool.' (19-20)

${ }^{1}$ The first five words of the title come from Ambrose Bierce's openly derisive, though suitably euphemistic description of dogs: "Snap-dogs, lap-dogs, always-on-tap-dogs / Smilers, Defilers / Reekers and Leakers" (qtd. in R. Morris 15). 
Boundaries symbolize the conservative, the stale, the conventional. In transgressing them, art violates its own rules, plays with the expectations and beliefs of the spectators, and is occasionally considered offensive and/or intolerable by the state. Paradoxically enough, modern-day audiences expect to be scandalized and taboo-breaking has become a convention itself: a desirable promoting strategy which ensures topicality while at the same time it attracts critical interest and acclaim.

Literature of the last two centuries has not been devoid of similar perils and temptations. As is the case with art, the nagging question remains as to what extent literature is capable of genuinely changing the world. Furthermore, the cultural and historical contexts in which transgression occurs, or is perceived as such, need examining as well as the correlation of the subversive qualities of literature with specific literary genres. In other words, transgression is not always a function of the writer's innovative approach or conscious strategy, and there can be no unanimous and permanent agreement as to which works of literature "deserve" to be called subversive and precisely what criteria should be applied in the process of classifying them as such. The inherent ambiguity of subversive and/or transgressive literature complicates matters even further. A typical lexicon entry defines subversion as either an "activity undermining government" or "overthrow of something: the destruction or ruining of something" ("Subversion") whereas transgression involves "action violating law or code, commission of wrongs, or overstepping limit" ("Transgression"). Indeed, the moral argument has often been used to denigrate or even condemn various writers' attempts at experimenting with new or controversial forms and subject matter.

Taking into account the lexical subtleties mentioned above, the satire genre would seem subversive by definition. After all, it "derides": it "uses laughter as a weapon, and against a butt that exists outside the work itself" (Abrams 275). While exposing "both human and institutional failures . . . greed, selfindulgence, drunkenness, incompetence, hypocrisy, intolerance, corruption, excesses, or partisanship" (L. Morris 377), the concerned satirist hopes to be able to inspire changes in the imperfect world, encouraging reform of not only the faulty sociopolitical structures, but also the very modes of thinking prevalent in the given society. As Brian Connery and Kirk Combe remind us, "Reading satire is doubly perilous, for satirists specialize in demolition projects. The one thing we know about satire is that it promises to tell us what we do not want to know - what we may, in fact, resist knowing" (1). The disturbing effect produced by various satirical pieces does not necessarily result solely from the controversial subject matter or stylistic exaggerations. Ultimately, it is the fact they constitute an idiosyncratic mode of mirroring and diagnosing the social reality, and expressing dissent (Quintero 1) that unsettles the reader and sometimes even energizes him or her into genuine action. 
In what follows I will discuss some of the ways in which the unorthodox and oftentimes disturbing presence and the ambivalent status of dogs in selected pieces of satirical prose contribute to their subversive potential while at the same time leading to considerable interpretive problems and inviting questions about the reception of the stories by contemporary readership. The works in question are "Never Bet the Devil Your Head" by Edgar Allan Poe, "Oil of Dog" by Ambrose Bierce and "A Dog's Tale" by Mark Twain. My justification for putting these three stories together is simple enough. Firstly, they belong to the satire genre and include dog-related themes. Secondly, they were written by eminent nineteenth-century American writers whose literary legacy continues to influence contemporary tastes and remains relevant to mass culture. It should also be emphasized that the tales have received far less critical attention than their authors' other literary works and that the interest from both reviewers and scholars has, rather frustratingly, gravitated towards the field of biographical criticism. Furthermore, there is a definite connection between the authors of the stories, with Bierce often being termed Poe's successor or imitator, and his brand of satire occasionally juxtaposed or contrasted with Twain's allegedly more good-natured humour. Last, but not least, even if the literary reputation of the three American writers suffered as a result of venturing into a traditionally less respected and frequently misunderstood genre, they undoubtedly excelled at it, experimented with its various brands and used it as a convenient platform for exposing and scorning the vices of the increasingly materialistic, self-absorbed and complacent society of their times.

\section{A Dog's Life}

An even cursory perusal of The Wordsworth Dictionary of Phrase and Fable reveals humans' longstanding ambivalence towards dogs ("Dog," Wordsworth 348-52). In fact, the majority of dog-related English phrases and colloquialisms bring negative associations with filth, degradation, worthlessness and crime, e.g., "a dirty dog," "to be in the doghouse," "love me love my dog" "dogs of war," "throw it to the dogs," "to die like a dog," "to go to the dogs," "dog-cheap" or "not to have a word to throw at a dog." Dogs have always been cherished for their loyalty, yet at the same time despised for their servility, dependent on their masters, essentially devoid of autonomy, passive and inferior.

American literature abounds in tales of dogs. At times they can be pretty disturbing. Harlan Ellison's "A Boy and His Dog," a 1969 short story, comes to mind in particular. In it Blood, a genetically mutated dog, functions as a telepathic pimp and a misanthrope who likes to comment upon the stupidity of humans. The end of the story suggests that the protagonist cooked his girlfriend 
in order to feed his loyal dog companion: an idea that might come as a shock, but which, in my opinion, is merely yet another instance of escalating misogynistic fantasies, made even more unpalatable in terms of reception precisely due to the presence of the canine component. An almost equally disturbing take on the ubiquity of "boy and his dog" stories in American culture has been offered by Eric Tribunella, who claims that the strong, affectionate relationships represent "a form of childhood sexuality that is often overlooked as such" (152).

Dogs in the above-mentioned tales by Poe, Bierce and Twain are integrated into the narrative in various ways, performing different roles and serving different agendas. It would seem that the varying levels of spite for those severely underrated creatures in the three writers' fictitious worlds pretty much reflect their despicable status in the real world and in this sense the creators help perpetuate the values cherished by the communities they indirectly attack.

\section{“Never Bet the Devil Your Head" and Dogged Morality}

While commenting on his short story "Berenice" in a letter to T. W. White, Poe announced the intention to express in writing "the ludicrous heightened into the grotesque: the fearful coloured into the horrible: the witty exaggerated into the burlesque: the singular wrought out into the strange and mystical" (qtd. in Meindl 47). Even more interestingly, he promised that he would not avoid the risk of going to "the very verge of bad taste" (47). "Never Bet the Devil Your Head" (1841), subtitled "A Tale With a Moral," certainly meets the criteria of a bizarre, at times hilarious, but mostly enigmatic grotesque genre, and it has been interpreted predominantly as a satire on Poe's contemporary literary establishment, especially the influential transcendentalists. Specifically, Poe is said to be "preoccupied or even obsessed by what he sees as transcendental hucksterism and what transcendentalism represents in a critical perspective: hypocrisy, callousness, and egotism" (Eisenhauer xi).

The narrator, who claims to be the author of the tale, responds to literary critics' accusations that his stories are not didactic enough and, having quoted profusely from various classics, proceeds to describe the short and rather violent life of Toby Dammit, his companion. It is, he assures the imagined community of readers (including reviewers), "a history about whose obvious moral there can be no question whatever, since he who runs may read it in the large capitals which form the title of the tale" ("Never Bet" 414).

Much in the spirit and tradition of tall tales, Toby Dammit is described as an unusually wicked person who, even as a pre-toddler, abuses alcohol, is a womanizer and grows up to become an obsessive gambler, but only in the 
rhetorical sense: he often makes bets and at some point starts to use the expression "I'll bet the devil my head" practically in every situation. The narrator in a matter-of-fact way expresses the conviction that Toby's vices should be ascribed to the improper way in which his mother flogged him, namely using left hand. ${ }^{2} \mathrm{He}$ also claims that he tried to persuade Dammit to drop his bad habits but to no avail.

One day, while on an excursion, the two men come across a bridge which is divided by a turnstile. Dammit bets the devil his head that he will leap over it and the narrator immediately notices a tiny old man who actually encourages Dammit to go through with the challenge. Unfortunately, Toby falls backwards during the jump and it turns out it is because he hit a horizontally placed sharp iron bar and got decapitated. The old man, who happens to be a devil, collects Toby's head. Since no one is inclined to pay funeral expenses, the narrator decides to sell his mutilated body "for dog's meat" (419).

In his study of subversion in modern literature, Keith Booker expresses a conviction that "to be politically effective, any literary transgression must have a strong communal element" as well as specific political and social targets (208). Seen from this perspective, Poe's satirical stories do not seem particularly "social" or focused on singular objects of ridicule. In fact, the author himself claimed that "Never Bet the Devil Your Head" was "a mere Extravaganza levelled at no one in particular, but pitting right and left at things in general" (Barger 412), with the targets ranging from homeopathists to literary hacks.

Whereas the familiar "bargain with the devil" motif carries the story and provides a necessary, if minimal, dose of suspense, the situational burlesque and enigmatic quality of the characters make it impossible to concentrate on the narrative and/or treat it seriously. The absurdity and improbability of the story are particularly striking as far as the unlucky protagonist is concerned. What the narrator observes about Toby's personality is reduced to his being nasty, poor and parsimonious (because of being poor). Paradoxically, much more can be inferred as far as the narrator's biased, growingly judgmental attitude towards Toby is concerned. He shows no empathy for his rude companion, cynically likens Toby's poverty to a vice and seems to be content with his imminent doom. In short, as Eliot Glassheim suggests, the narrator "shows himself to be a pompous, obtuse moralizer" (44).

The effect of defamiliarization is certainly intensified by the narrator's constant references to the peculiar, dog-like behaviour on the part of the obsessive gambler, such as "He was a sad dog, it is true, and a dog's death it was

${ }^{2}$ In Mary Grenander's opinion, the passage about corporal punishment brings immediate associations with Jonathan Swift's "A Tale of a Tub," where Swift's persona writes: "Last week I saw a woman flayed, and you will hardly believe how much it altered her persona for the worse" (qtd. in Grenander 132). 
that he died; but he himself was not to blame for his vices" (414), "Nothing would serve him but wriggling and skipping about under and over every thing that came in his way" (416) and

[a]t five months of age he used to get into such passions that he was unable to articulate. At six months, I caught him gnawing a pack of cards. At seven months he was in the constant habit of catching and kissing the female babies. At eight months he peremptorily refused to put his signature to the Temperance pledge. Thus he went on increasing in iniquity, month after month, until, at the close of the first year, he not only insisted upon wearing moustaches, but had contracted a propensity for cursing and swearing, and for backing his assertions by bets. $(414)^{3}$

While discussing the merits of Toby Dammit, a film adaptation of "Never Bet the Devil Your Head," Christopher Sharrett treats the film as "Fellini's meditation on the erasure of the subject through the erasure of the subject through the erasure of the actor: that is, the end of the artist as manipulated figure subscribing to a 'corporate vision' of art" (124). Toby is "an actor without a voice" (129), "the emblem of failed signification" (129) and "a puppet, a functionary within the avenue of illusion" (131). Arguably, a similar process occurs in the literary original: Toby from the very beginning functions as a defective, fragmented character, deprived of his own voice and palpable identity, bound to disintegrate in a clever game of words.

\section{The Impossibility of Story-telling}

Several scholarly analyses of "Never Bet the Devil Your Head" concentrated on the more or less obscure references to the mid-nineteenth century literary life in the United States, a useful strategy for establishing the precise targets of Poe's taunts. Other investigative efforts aimed at locating the story within Poe's satirical oeuvre, especially in terms of obsessively recurring themes and motifs, e.g., body mutilations, for comic effect. Of equal interest, however, is that aspect of the story which enables reading it as a commentary on the absurdity and futility of both story-telling and story-interpreting, and in this sense Poe's "minor, farcical" tale (Joshi 170) transgresses the typical confines of the satire genre.

Since in his introductory remarks the narrator comments profusely on the issue of literary didacticism and the moral has already been included in the title of the story, one could reasonably argue that there is no point in telling the rest

3 A detailed analysis of Toby's dog-like qualities and behaviours was offered by Eliot Glassheim, who went as far as to claim that Toby “is, in literal fact, a dog” (45). 
of the tale. And indeed, what follows seems to be an almost gratuitous exercise in offending rules of narration and limits of plausibility. Furthermore, language itself "betrays" and undermines both the credibility of the narrator and the story, though at the same time linguistic puns and figures of speech employed by Poe are very effective in conveying its overall satirical purpose. To give a striking example, "Never Bet the Devil Your Head" heavily relies on such rhetorical devices as antonomasia, "a trope that involves the substitution of an epithet, a descriptive word or phrase, for a proper name or any common noun - or vice versa" (Zimmerman 136), and exemplum, "a cited example that may be either true or mythical; a story or anecdote cited to illustrate a moral or a doctrine" (Zimmerman 215). Amusingly enough, their presence constitutes a potential self-parody of Poe's abundant use of scientific jargon and obscure literary references:

The truth is, there was something in the air with which Mr. Dammit was wont to give utterance to his offensive expression - something in his manner of enunciation - which at first interested, and afterwards made me very uneasy - something which, for want of a more definite term at present, I must be permitted to call queer; but which Mr. Coleridge would have called mystical, Mr. Kant pantheistical, Mr. Carlyle twistical, and Mr. Emerson hyperquizzitistical. ("Never Bet" 415)

In this rhetorical void, the main character is reduced to "now shouting out, and now lisping out, all manner of odd little and big words, yet preserving the gravest face in the world all the time" (416). With a considerable help from his "friend," the decisively unfriendly narrator, Toby has been deprived of convincing motivation; stripped down to clichés; made to look preposterous, disturbing, impenetrable and ultimately useless. Even his propensity for rhetorical bets, the very basis of the tale, is put into question by the narrator, who admits to being inefficient, possibly untrustworthy:

With him the thing was a mere formula - nothing more. His expressions on this head had no meaning attached to them whatever. They were simple if not altogether innocent expletives imaginative phrases wherewith to round off a sentence. But these are my own reflections and I am by no means sure that I am right in attributing them to him. (414)

As if to ridicule the notion that fiction is rich with ideas and thus worthy of interpretive efforts which, in turn, are perfectly legitimate, the narrator in "Never Bet the Devil Your Head" has the following comment to offer at the beginning of the tale:

[I]t has been shown that no man can sit down to write without a very profound design. Thus to authors in general much trouble is spared. A novelist, for example, need have no care of his moral. It is there - that is to say, it is somewhere - and the moral and the critics can take care of themselves. When the proper time arrives, all that the gentleman intended, and all that 
he did not intend, will be brought to light, in the "Dial," or the "Down-Easter," together with all that he ought to have intended, and the rest that he clearly meant to intend: - so that it will all come very straight in the end. (413)

Poe had to be aware his story would baffle and mystify even his most cultivated, reference-catching readers. His taunt towards the critical establishment might be perceived as a symbolic act of shooting himself in the foot, yet it encourages uncomfortable questions concerning deeper intents and hidden agendas that are worth searching for and unearthing for the sake of the reading community. With the benefit of hindsight, one is almost tempted to ask whether "Never Bet the Devil Your Head" fully warrants the critical attention it has been accorded (regardless of how scant the attention may seem in comparison with the critical interest inspired by Poe's horror stories). Perhaps while trying to uncover the meaning of a work of literature, scholars are guilty of a similar transgression: that of seeing profundity and deliberateness in a story which may be characterized by neither.

\section{“Oil of Dog" and Dogged Business}

"Oil of Dog" (1890) belongs to The Parenticide Club cycle 4 of stories which have for many years been considered disgusting, unnecessarily brutal and devoid of any redeeming qualities. Roy Morris termed this dog-related effort a "hairraising tale" (11) and added, in an exasperated tone: "The fact that these stories were intended to be - and are, in a somewhat grisly way - funny, makes them seem, if anything, even more terrible" (11). Clearly, the notion of black humour and its espousal of controversial topics has often provoked discomfort, rather than genuine amusement or serious analysis, from those critics who seem to have opted for the relatively safer territory of Bierce's war and supernatural tales.

The beginning of the story offers a representative introduction to Bierce's style and promises a crazy world in which all moral values are perverted or suspended, and murdering people and animals out of expediency, greed or pure sadism is treated as a perfectly understandable strategy:

My name is Boffer Bings. I was born of honest parents in one of the humbler walks of life, my father being a manufacturer of dog-oil and my mother having a small studio in the shadow of the village church, where she disposed of unwelcome babes. In my boyhood I was trained to habits of industry; I not only assisted my father in procuring dogs for his vats, but was frequently employed by my mother to carry away the debris of her work in the studio. (427)

\footnotetext{
${ }^{4}$ The remaining three stories are "My Favorite Murder," "The Hypnotist" and "An Imperfect Conflagration." In each of them, the narrator's parents or close relatives die as a result of his outrageous actions.
} 
However, on one occasion Boffer is followed by a suspicious constable and is forced to cast the body of a foundling into the cauldron in his father's oil factory. As a result, the father obtains oil of unusually fine quality and it occurs to him and his wife that they should think about "combining their industries" and start producing oil of babies. People living in the town are not enthusiastic about the possibility of "any further raids upon the population." Angered by the citizens' resolution, the parents get rid of them and prepare secretly to kill each other: the woman stabs her husband but he manages to drag her into the cauldron, in which both die. The narrator leaves the city, greatly disappointed with this "commercial disaster" and, apparently, remorseful because of his role in it.

Mary Grenander classified The Parenticide Club stories as absurd mimetic tales of action (80) and established that, in realizing his satirical vision, Bierce used primarily a reverse of genuine standards, hyperbolic exaggeration and understatement (131). The euphemistic way of telling the story seems to contribute most to its irresistibly comical effect. For instance, the final struggle between Boffer's parents is called by the narrator "a disagreeable instance of domestic infelicity" (430) and the fatal stabbing invites the following comment: "My father's breast and my mother's weapon showed evidences of contact" (430). In fact, it is precisely the incongruity between the narrator's eloquent - if somewhat pompous - diction and the horrific nature of the plotline that constitutes the principal source of humour. While commenting on Bierce's style, particularly in reference to his satirical stories, Martin Jay writes about

the war between, on the one hand, his language - a language so savage that it is almost out of control, in which invective leads to vituperation and vituperation to frenzy; and, on the other hand, the forms he employs, whose tendency is to blunt, to efface, and to tolerate weakness. (213)

All in all, it seems that "Oil of Dog" relies on a risky, but effective coupling of style and content.

Bierce's choices of style and subject matter contribute a great deal to the sense of awkwardness and embarrassment on the part of the readers. His inverted tale of the rise and fall of a controversial business enterprise has even been termed "so outlandishly grotesque ... that it makes one a little bit ashamed to laugh" (Quirk 143). Incidentally, Quirk's verdict helps understand why it took many decades to secure the sardonic author's literary reputation but does not seem entirely fair or accurate from the point of view of the expectations carried by the very convention Bierce used in his parricide cycle. The fictitious universe created by Bierce may be considered completely unrealistic and/or morally abhorrent, yet it rarely ventures beyond the generic boundaries of the grotesque: 
$[\mathrm{N}]$ otwithstanding the multiplicity of scholarly treatments of the grotesque, there exists a certain amount of agreement as regards its essential nature. The grotesque emerges as a tense combination of attractive and repulsive elements, of comic and tragic aspects, of ludicrous and horrifying features. ... Without a certain collision of complicity between playfulness and seriousness, the grotesque does not appear to exist. (Meindl 14)

The remarks concerning the quality of Bierce's humour do not seem to do justice to his satirical stories either. For instance, Lee characterizes Bierce's humour as "heavy, crude, cruel, physically violent, almost universally misanthropic, but above all misogynous" (137-38), a perspective that makes sense, but imposes a dead-serious interpretation of "Oil of Dog" as primarily an expression of moralistic concerns. Ironically enough, Boffer Bings is a perfect product of both Victorian sentimentalism and the Gilded Age. Even though the story was treated by several critics as a defence of parenticide, on closer inspection it offers a portrayal of a loving, hard-working family. The narrator repeatedly refers to one of his parents as "my dear mother," whose "holy influence" (429) helped him avoid the temptations of youth. Unfortunately, a minor mishap on the part of the narrator leads to the destruction of the Puritan work ethos and the holy familial bonds: values whose importance seems to overshadow the complicit role of the local church, authorities and ordinary citizens in tolerating such crimes as illegal abortions or stealing and murdering animals.

As is usually the case with the work of satirists, Bierce's tale has frequently been viewed in terms of his personal life and experiences. To give a typical example of such biographical fallacy, Jay claims that in The Parenticide Club stories Bierce "imitates in overt action the kind of psychic tensions in family life that alienist psychoanalysts would later describe" (216-17), whereas Tom Quirk seems to be torn between the constructedness of the fictitious world offered by Bierce and the influence of the creator's life on the content of "Oil of Dog": "It is not at all clear ... how much of his supposed bitterness was temperamental and how much contrived, and it is to overestimate the depth of his resentment" (116). On the other hand, Talley opts for a fairly pragmatic, middle-of-the-road approach which, in her opinion, allows for a more comprehensive take on Bierce's oeuvre. Talley uses a post-Freudian perspective to account for the recurrent themes of family violence and parricide in Bierce's short stories, claiming that The Parenticide Tales "arguably contain both conscious satirical content and unconscious biographical content that should be considered together for a full understanding" (7). More specifically, "Oil of Dog" could then be described as a "depiction of a fictional child's struggle to resolve ambivalent emotions that reflect the heritage of Bierce's own childhood experiences" (8).

While a detailed consideration of the terms of the biographical fallacy debate would go beyond the scope of this paper, there is at least one good reason 
why the extratextual factors could, and perhaps should, be taken into account in a thorough discussion of "Oil of Dog." Bierce's work as a journalist, lexicographer, short-story writer and satirist shows a remarkable unity as far as his worldview, topical preoccupations and stylistic idiosyncrasies are concerned. For example, for an analysis of the possible significance of dogs or, for that matter, of animals in general, in Bierce's stories, it does not seem entirely unreasonable to draw upon the biographical resources and The Devil's Dictionary, a product of Bierce's work as a columnist in various San Francisco newspapers and magazines. Berkove went as far as to propose that all satirical works by Bierce should be understood as "fictional counterparts to his attacks on social ills" (141) in the above-mentioned journalistic columns.

According to Roy Morris, Bierce hated dogs because of "their slavish need for affection and approval" (15), an assumption that could be easily countered, for instance, by claiming that the author of "Oil of Dog" hated women much more consistently or that he abhorred animals in general, even the domestic ones. ${ }^{5}$ More convincing evidence of Bierce's cynicism and unease about the presence of canine quadrupeds in the world can be found in The Unabridged Devil's Dictionary, a collection of entries satirizing selected English words, where Bierce defines the dog as an obsolete, useless creature:

It must seem to the Dog that the substances, methods and functions of nature are arranged with special reference to his needs, his capacities, his future. He can hardly help thinking himself gifted with peculiar advantages and inheriting the earth. Yet the rascal is an anachronism who exhausted his mandate ages and ages ago, and lags superfluous on the stage. He is a 'survival' who since the dawn of civilization has had no function and no meaning. Our love for him we have inherited along with many other instincts transmitted from our savage past. If there have never been a dog and one were created, we should fall foul of him with hard substances and a clamor of tongues. He would seem uglier than a reporter, and more hateful than a poet. (294)

An alternative, slightly simpler and more straightforward definition of the dog suggests that, according to Bierce, this animal is

[a] kind of additional or subsidiary Deity designed to catch the overflow and surplus of the world's worship. This Divine Being in some of his smaller and silkier incarnations takes, in the affection of Woman, the place to which there is no human male aspirant. The Dog . . toils not, neither does he spin, yet Solomon in all his glory never lay upon a door-mat all day long, sun-soaked and fly-fed and fat, while his master worked for the means wherewith to purchase the idle wag of the Solomonic tail, seasoned with a look of tolerant recognition. ("Dog," Devil's Dictionary)

5 "A Cargo of Cat," a curious tall tale in which the death of thousands of cats is described in a detailed, almost sadistic manner, seems to be quite telling in this respect. 
It is, therefore, hardly surprising that dogs in the story under analysis are used in a purely instrumental way and their role is reduced to being passive victims of human greed or medicinal ingredients. Funnily enough, however, it is the body of a human baby that turns out to be the agent of contamination and sets in motion an avalanche of gruesome events: a powerful reminder that the strategy of "subversive inversion" has been used consistently and fearlessly throughout the story.

"Oil of Dog" provides an apt illustration of the attitude described by Quintero, according to whom "satirists do not wither in despair but, on the contrary, feel compelled to express their dissent" (1). Bierce's story presents "a world not all that removed from the one we know" (Berkove 149): "This world is not wholly imaginary, except, perhaps, in the transparency of its hypocrisy" (148). It is precisely the familiarity of what Bierce satirizes that constitutes the most disturbing aspect of the story and attests to its endurance and popularity.

\section{“A Dog's Tale" and Dogged Religiosity}

“A Dog's Tale" was published in Harper's Monthly and as a pamphlet by the National Vivisection Society in 1903, with Mark Twain's approval, and as a book one year later (Mason 183). The story is told entirely from the point of view of Aileen Mavourneen, a dog who has no idea of the real significance of the events she describes in a detailed, passionate way. The first chapter of the narrative is devoted to Aileen's mother, who shows extraordinary skills in memorizing and imitating complicated words used by human beings. Aileen loves and admires her mother but is pretty soon sold and taken away to a new home, for reasons which she cannot comprehend. While living with the family, she saves her new owners' baby by dragging it away from the nursery in which a fire breaks out. Unfortunately, the baby's father mistakes Aileen's help for aggression. Beaten by its master, the dog spends much time hiding but comes back in favour once the truth about her heroism is revealed. Although Aileen is loved and praised by the family, the master does not hesitate to maim and kill her puppy during a biological experiment aimed at checking whether a specific brain injury would cause blindness. The puppy is buried in the family garden and Aileen naively believes it will "come up" like a flower. Having spent two weeks on the grave, Aileen is weakened with grief and close to death herself.

The very beginning of "A Dog's Tale" - "My father was a St. Bernard, my mother was a collie, but I am a Presbyterian" (351) - shows how confused and/or ignorant of the reality the naive dog-narrator is. In addition, it promises that the tone of the story will be invariably comical. However, what follows is an unrestrained, grim, melodramatic tale that offers no redemption for the abused 
canine protagonist. The only humorous part of the tale is a result of exploiting "the gap between human speech and animal comprehension" (Messent 197). Thanks to listening intently to whatever is being said at home and in the Sunday school, the mother knows how to imitate "fine large words" (351), a skill that is greatly admired and makes other dogs envious. She earns the reputation of "the only cultivated dog" (352) in the community:

\begin{abstract}
She had one word which she always kept on hand, and ready, like a life-preserver, a kind of emergency word to strap on when she was likely to get washed overboard in a sudden way that was the word Synonymous. When she happened to fetch out a long word which had had its day weeks before and its prepared meanings gone to her dump-pile, if there was a stranger there of course it knocked him groggy for a couple of minutes, then he would come to, and by that time she would be away down wind on another tack, and not expecting anything; so when he'd hail and ask her to cash in, I (the only dog on the inside of her game) could see her canvas flicker a moment - but only just a moment - then it would belly out taut and full, and she would say, as calm as a summer's day, "It's synonymous with supererogation," or some godless long reptile of a word like that, and go placidly about and skim away on the next tack, perfectly comfortable, you know, and leave that stranger looking profane and embarrassed, and the initiated slatting the floor with their tails in unison and their faces transfigured with a holy joy. (352)
\end{abstract}

Parallels with the experience of taking part in the holy mass are unmistakable. In fact, details included in the clueless narrator's descriptions make it impossible not to take a religious perspective into account. Supporters of the biographical and/or historical paradigm in literary studies would be equally justified in choosing this investigative venue. After all, the well-known sayings attributed to Mark Twain, such as "Faith is believing what you know ain't so" or "If Christ were here now there is one thing he would not be - a Christian," speak volumes about his attitude towards organized religion, and some of his essays and works of fiction, e.g., The Mysterious Stranger or Letters from the Earth (both published posthumously), only confirm his tendency to ridicule the principles of Christianity.

Aileen's mother is a dog version of a priest, and a great pretender to boot. She obviously benefits from her privileged status as a canine intermediary, always ready to ridicule the "sceptics," to brand them publicly as stupid and unworthy. The dogs, in turn, behave like the faithful who are either not interested or unable to interpret or question the canine "Gospel." Clueless, but in awe, they follow their "spiritual leader" blindly. Mob mentality is for them a guarantee of not getting in trouble, its mechanism all the more depressing since it hinges upon all things spiritual.

But false religiousness seems to be a minor target in "A Dog's Tale." The notion that the afterlife will somehow compensate for the tribulations of earthly life (an option available only to humans in Twain's story), and that because of 
that vision of bliss creatures should humbly accept whatever fate has in store for them, proves disastrous in the case of the narrator-protagonist. The teachings of Aileen's mother inculcate in her young, unsuspecting mind the belief that humility and passive acceptance are inherently good and thus constitute the only natural response to whatever Providence might have decreed:

\begin{abstract}
When I was well grown, at last, I was sold and taken away, and I never saw her [my mother] again. She was broken-hearted, and so was I, and we cried; but she comforted me as well as she could, and said we were sent into this world for a wise and good purpose, and must do our duties without repining, take our life as we might find it, live it for the best good of others, and never mind about the results; they were not our affair. She said men who did like this would have a noble and beautiful reward by and by in another world, and although we animals would not go there, to do well and right without reward would give to our brief lives a worthiness and dignity which in itself would be a reward. (353)
\end{abstract}

The consistently used anthropomorphism whereby human motivations and view of the world are attributed to an animal produces a highly ironic outcome. Unconditional trust and obedience: qualities which are demanded from the faithful but which can also be perceived as symptoms of passivity and fear, bring about a tragic conclusion for Aileen and her puppy. Had she been less gullible and humble, she would have been able to save her offspring and herself. An additional irony consists in the fact that dogs in Twain's fictitious universe prove to be much less beastly and much more moral than their human owners.

As far as the reception of the controversial story by Twain's contemporaries is concerned, "A Dog's Tale" was often termed charming, sentimental and extremely moving but treated mainly as an indictment of vivisectionism. "Of course, sentiment is not argument," a reviewer from Charleston Sunday News wrote, somewhat dismissively (Budd 541). Others referred to "a charming blend of humour and pathos" and "one of the best dog stories" (Budd 541), or conversely, claimed "it is not a story at all, but an anti-vivisectionist tract" (541). A different tone can be found in the review published anonymously in the "Novels" section of 1905 Saturday Review, especially since an attempt is made at offering a more formal analysis of Twain's work: "Mark Twain has spoiled the effect of a story designed to protest against scientific cruelty by very tedious and pointless jocularity at the outset" (Budd 541-42). The reviewer criticizes "unreal devices" (such plot points as the vivisection of the puppy whose mother rescued the owner's kid) and concludes the rather harsh assessment with the following parting shot: "Mr Smedley's four illustrations show more understanding of dogs than is to be found in the text, which will only appeal to sentimentalists" (Budd 542). To sum up, no comment was made about the religious dimension of the story, the accusation of humanity and its gullibility. The reviewers play a safe game: they content themselves with pinpointing the 
more or less obvious weaknesses of Twain's tale, while refusing to touch upon its most explosive aspect.

What such modern-day scholars as Peter Messent or James Cox seem to have in common is their lack of inclination to dwell on the antireligious message of Twain's story. Curiously enough, their remarks are to a large degree reminiscent of the objections cited above. In particular, their criticism tends to be focused on the formulaic, Victorian, "cloying" sentimentality and predictable representations of gender (Messent 194, 195). Cox also classifies the story in the "sentimental category" and "more or less nauseating short fiction" (265). By contrast, Peter Stoneley argues stories such as "A Dog's Tale" "are conveniently dismissed as the sentimental effusions of an aged and lonely man" (104), and Leland Krauth expresses the conviction that

to become sentimental in order to drive home a moral point is, for Mark Twain, neither a lapse, nor an aberration, nor a failing of old age: it is a fundamental gesture in his writing. It occurs in his best fiction as well as his strongest polemical essays. (38)

A different point of departure is adopted by Mary Henninger-Voss, who firmly locates Twain's story in the historical and literary context of the era, noticing that animals as first-person narrators started to be used "most heavily and effectively after 1870, after the conventions of the domestic ethic of kindness were fully articulated" (349).

Similarly to Poe's and Bierce's stories, Twain's work has often been commented upon and assessed through the lens of biographical criticism. In a typical example of such a tendency, Kristin Brown asks rhetorically: "[W]hy should Samuel Clemens have been in a humorous mood, faced with bankruptcy, the death of a child, and his wife's terminal illness?" On the other hand, taking into account Twain's very high public profile and mainstream recognition, and the all-encompassing, effusive praises such as Faulkner's "the father of American literature," it is actually quite surprising that the humorist's rebellious streak has continued to provide a viable scholarly perspective in the more recent decades.

The familiar "writer-as-rebel" meme has been used in connection with Twain's oeuvre by numerous academics and reviewers, except that the reliance on the notion of "a sanctioned rebel," who is capable of outraging a community, albeit within acceptable limits, has gradually given way to either a more thorough exploration of Twain's hitherto underappreciated darker satires or to more raced and gendered readings of his work in general. Bruce Michelson, in particular, draws attention to the "more subversive and anarchist dimensions" of Twain's works, claiming that the wilder, more outrageous aspect of his humour

\footnotetext{
${ }^{6}$ A conscious reference to Judith Fetterley's essay on the transformation of Tom Sawyer.
} 
has been systematically neglected, and calls Twain "the best escape artist in the American canon," someone who breaks the rules instead of conforming to them (233). In a similar vein, Peter Messent concentrates on the "generic instabilities in Twain's texts" (19) and argues that the emphasis on "such instability, incongruity, and shifting perspective, provides a paradigm for Twain's work as a whole" (2). Such collections of Twain-related essays as Constructing Mark Twain: New Directions in Scholarship or A Historical Guide to Mark Twain (published in 2001 and 2002, respectively), demonstrate the wish to capture the author's life and work in all of their complexity and seem to augur more "revisionist" attempts in the near future. In the case of an author whose humour "subvert[s] the expectations of subversion" (Brykman) and who is difficult to place in the American literary tradition (Oggel 48), the scenario for constant critical reassessment sounds entirely plausible.

\section{Conclusion}

In juxtaposing Ashley Tauchert's pronouncement that transgression "has become a critical and cultural icon of radical nonconformity, an unvoiced insistence that the proper role of the intellectual is resistance" against "oppressive boundaries" (2) with Keith Booker's notion that transgressive literature "works more subtly, by gradually chipping away at certain modes of thinking that contribute to the perpetuation of oppressive political structures" (4), one arrives at a fairly accurate assessment of the literary effort by Edgar Allan Poe, Ambrose Bierce and Mark Twain. Often labelled iconoclasts, rebels and nonconformists, the above-mentioned creators were charged a rather exorbitant price for exceeding boundaries, norms and expectations. Not surprisingly, but rather disappointingly, even nowadays critical attention tends to concentrate on those literary achievements of Poe, Bierce and Twain that are easier to categorize and assess, and that do not challenge the dominant social order in such a blatant fashion.

A more detailed examination of "Never Bet the Devil Your Head," "Oil of Dog" and "A Dog's Tale" makes it possible to suggest that they exhibit a level of ambiguity and a dose of bitterness rarely encountered in mainstream American literature. However, those same properties have been responsible for either lukewarm or distrustful, or downright hostile, responses of the nineteenthcentury reading public. In retrospect, one can argue that even if the three authors' potent mixture of cynicism and idealism could not radically change the world, it at least retains the ability to attract the attention of contemporary readers and provoke questions about the nature and the limits of cultural subversion in the societies which have more often than not refused to appreciate its goals and achievements. 


\section{Works Cited}

Abrams, M. H. A Glossary of Literary Terms. 7th ed. Boston, MA: Heinle and Heinle, 1999. Print. Barger, Andrew, ed. Edgar Allan Poe: Annotated and Illustrated Entire Stories and Poems. Memphis, TN: Bottletree Books, 2008. Print.

Berkove, Lawrence. A Prescription for Adversity: The Moral Art of Ambrose Bierce. Columbus: Ohio State University, 2002. Print.

Bierce, Ambrose. "A Cargo of Cat." The Complete Short Stories of Ambrose Bierce. Comp. Ernest Jerome Hopkins. Foreword by Cathy N. Davidson. Lincoln: University of Nebraska Press, 1984. 494-96. Print.

---. "Oil of Dog." The Complete Short Stories of Ambrose Bierce. Comp. Ernest Jerome Hopkins. Foreword by Cathy N. Davidson. Lincoln: University of Nebraska Press, 1984. 427-30. Print.

---. The Unabridged Devil's Dictionary. Ed. David E. Schultz and S. T. Joshi. Athens: University of Georgia Press, 2002. Print.

Booker, Keith M. Techniques of Subversion in Modern Literature. Transgression, Abjection, and the Carnivalesque. Gainesville: University of Florida Press, 1991. Print.

Brown, Kristin. Rev. of Mark Twain: The Fate of Humor, by James M. Cox. N.p., n.d. Web. 17 Oct. 2009.

Brykman, Steven. Rev. of Mark Twain on the Loose: A Comic Writer and the American Self, by Bruce Michelson. Mark Twain Forum. 20 Aug. 1996. Web. 11 Oct. 2009.

Budd, Louis J, ed. Mark Twain: The Contemporary Reviews. Cambridge: Cambridge University Press, 1999. Print.

Connery, Brian A., and Kirk Combe, eds. Theorizing Satire. Essays in Literary Criticism. New York: St. Martin's Press, 1995. Print.

Cox, James M. Mark Twain: The Fate of Humor. Princeton, NJ: Princeton University Press, 1966. Print.

"Dog." The Devil's Dictionary. N.p., n.d. Web. 21 Feb. 2010.

"Dog." The Wordsworth Dictionary of Phrase and Fable. Based on the original book of Ebenezer Cobham Brewer. Rev. by Ivor H. Evans. Hertfordshire: Wordsworth Editions, 1993. 348-52. Print.

Eisenhauer, Robert. "Sinful Reading: Fellini's Toby Dammit and Poe's 'Never Bet the Devil Your Head." After Romanticism. Studies on Themes and Motifs in Literature. New York: Peter Lang, 2008. 133-51. Print.

Ellison, Harlan. Short Stories by Harlan Ellison. N.p.: Books LLC, 2010. Print.

Fetterley, Judith. "The Sanctioned Rebel." Studies in the Novel 3.3 (Fall 1971): 293-304. Print.

Glassheim, Eliot. “A Dogged Interpretation of 'Never Bet the Devil Your Head.'” Poe Newsletter 2.3 (Oct. 1969): 44-45. Print.

Grenander, Mary E. Ambrose Bierce. New York: State University of New York at Albany, 1971. Print.

Henninger-Voss, Mary J. Animals in Human Histories: The Mirror of Nature and Culture. Rochester, NY: University of Rochester Press, 2002. Print.

Jay, Martin. "Ambrose Bierce." The Comic Imagination in American Literature. Ed. Louis D. Rubin, Jr. Washington, DC: Voice of America, 1974. 207-17. Print. Voice of America forum series.

Joshi, S. T. Icons of Horror and the Supernatural: An Encyclopaedia of Our Worst Nightmares. Westport, CT: Greenwood Press, 2007. Print.

Julius, Anthony. Transgressions: The Offences of Art. London: Thames and Hudson, 2002. Print. 
Krauth, Leland. Mark Twain \& Company: Six Literary Relations. Athens: University of Georgia Press, 2003. Print.

Lee, A. Robert. The Nineteenth-Century American Short Story. London: Vision Press, 1986. Print. Critical Studies Series.

Mason, Jennifer. Civilized Creatures: Urban Animals, Sentimental Culture, and American Literature, 1850-1900. Baltimore: John Hopkins University Press, 2005. Print.

Meindl, Dieter. American Fiction and the Metaphysics of the Grotesque. Columbia: University of Missouri Press, 1996. Print.

Messent, Peter. The Short Works of Mark Twain: A Critical Study. Philadelphia: University of Pennsylvania Press, 2001. Print.

Michelson, Bruce. Mark Twain on the Loose: A Comic Writer and the American Self. Amherst: University of Massachusetts Press, 1995. Print.

Morris, Linda A. "American Satire: Beginnings through Mark Twain.” A Companion to Satire. Ed. Ruben Quintero. Malden: Blackwell, 2007. 377-99. Print.

Morris, Roy. Ambrose Bierce: Alone in Bad Company. Oxford: Oxford University Press, 1995. Print.

New, Melvyn. "Modes of Eighteenth-Century Fiction." Encyclopedia of Literature and Criticism. Ed. Martin Coyle, Peter Garside, Malcolm Kelsall, and Jon Peck. London: Routledge, 1990. 505-17. Print.

Oggel, Terry. "In His Own Time: The Early Academic Reception of Mark Twain." The Mark Twain Annual 1.1 (2003): 45-60. 28 June 2008. Web. 11 Jan. 2010.

Poe, Edgar Allan. "Never Bet the Devil Your Head." Edgar Allan Poe: Annotated and Illustrated Entire Stories and Poems. Ed. and introd. Andrew Barger. Memphis, TN: Bottletree Books, 2008. 413-19. Print.

---. The Other Poe: Comedies and Satires. Ed. and introd. David Galloway. New York: Penguin Books, 1983. Print.

Quintero, Ruben. "Introduction: Understanding Satire." A Companion to Satire. Ed. Quintero. Malden: Blackwell, 2007. 1-11. Print.

Quirk, Tom. Nothing Abstract: Investigations in the American Literary Imagination. Columbia, MO: University of Missouri Press, 2001. Print.

Sharrett, Christopher. "Toby Dammit, Intertext, and the End of Humanism." Federico Fellini. Contemporary Perspectives. Ed. Frank Burke and Marguerite R. Walker. Toronto: University of Toronto Press, 2002. 121-36. Print.

Stoneley, Peter. Mark Twain and the Feminine Aesthetic. Cambridge: Cambridge University Press, 1992. Print.

"Subversion." Encarta Encyclopedia. World English Edition. Microsoft Corporation, 1996. CDROM.

Talley, Sharon. "Childhood and the Fear of Death in The Parenticide Club and "Visions of the Night." Ambrose Bierce and the Dance of Death. Knoxville: University of Tennessee Press, 2009. 1-15. Print.

Tauchert, Ashley. "Among the Dark Satanic Wheels: Transgressing Transgression.” Introduction. Critical Quarterly 47.3 (Oct. 2005): 1-11. Print.

"Transgression." Encarta Encyclopedia. World English Edition. Microsoft Corporation, 1996. CD-ROM.

Tribunella, Eric. "A Boy and His Dog: Canine Companions and the Proto-Erotics of Youth." Children's Literature Association Quarterly 29.3 (Fall 2004): 152-71. Web. 15 Sept. 2009.

Twain, Mark. "A Dog's Tale." The Complete Short Stories of Mark Twain. Stilwell: Digireads.com., 2008. 351-57. Digireads. Web. 21 Feb. 2010.

Zimmerman, Brett. Edgar Allan Poe: Rhetoric and Style. Montreal: McGill-Queen's University Press, 2005. Print. 